Connecticut College

Digital Commons @ Connecticut College

Government and International Relations Faculty

Government and International Relations

Publications

Department

Spring 2020

Party-Political Responses to the Alternative for Germany in

Comparative Perspective

David F. Patton

Follow this and additional works at: https://digitalcommons.conncoll.edu/govfacpub

Part of the Political Science Commons

This Article is brought to you for free and open access by the Government and International Relations Department at Digital Commons @ Connecticut College. It has been accepted for inclusion in Government and International Relations Faculty Publications by an authorized administrator of Digital Commons @ Connecticut College. For more information, please contact bpancier@conncoll.edu.

The views expressed in this paper are solely those of the author. 


\title{
Party-Political Responses to the Alternative for Germany in Comparative Perspective
}

\begin{abstract}
In September 2017, the Alternative for Germany (AfD) became the first far-right party to join the Bundestag in nearly seventy years. Yet, it was not the first time that a challenger party entered the parliament to the chagrin of the political establishment. After introducing the AfD, the BHE, the Greens, and the Party of Democratic Socialism (PDS), the article analyzes how established parties treated the newcomers and why they did so. This comparative perspective offers insights into the AfD's challenge, how distinctive the policies toward the AfD have been, and why the established parties have dealt with the AfD as they have.
\end{abstract}

\section{Keywords}

Alternative for Germany (AfD), BHE, challenger parties, Greens, Party of Democratic Socialism (PDS), populist parties

\section{Disciplines}

Political Science

\section{Comments}

Originally published in German Politics and Society, Issue 134 Vol. 38, No. 1 (Spring 2020): 77-104 @ Georgetown University and Berghahn Books

doi:10.3167/gps.2020.380105 


\title{
Party-Political Responses to the Alternative for Germany in Comparative Perspective
}

\section{David F. Patton}

Government and International Relations, Connecticut College

\begin{abstract}
In September 2017, the Alternative for Germany (AfD) became the first far-right party to join the Bundestag in nearly seventy years. Yet, it was not the first time that a challenger party entered the parliament to the chagrin of the political establishment. After introducing the AfD, the BHE, the Greens, and the Party of Democratic Socialism (PDS), the article analyzes how established parties treated the newcomers and why they did so. This comparative perspective offers insights into the AfD's challenge, how distinctive the policies toward the AfD have been, and why the established parties have dealt with the AfD as they have.
\end{abstract}

Keywords: Alternative for Germany (AfD), BHE, challenger parties, Greens, Party of Democratic Socialism (PDS), populist parties

$\mathscr{T}$ September 2017, the Alternative for Germany (AfD) became the first far-right party to join the Bundestag in nearly seventy years. Against the backdrop of Germany's Nazi past, the AfD's advance has been troubling for Germany's established parties, which face difficult choices on how to respond to this unwelcome newcomer. ${ }^{1}$ Scholars have fruitfully explored how mainstream European parties have responded to new challenger parties. This article extends this comparative lens to postwar German cases. After all, it is not the first time that a challenger party joined the Bundestag to the chagrin of the political establishment.

In 1953, a refugee party-Bloc of Expellees and Those Deprived of Rights (BHE) entered the Bundestag after securing 5.9 percent of the vote. It contained those favoring a pragmatic approach to improving the lives of German expellees from the east and others who tended toward rightwing extremism with the goal of recovering the lands of those forcibly displaced. Three decades later, the West German Greens joined the Bundestag after winning 5.6 percent in national elections. Arising from the social movements of the 1970s, they saw themselves as an alternative to the establishment and called for sweeping reforms, such as West Germany's unilateral disarmament 
and neutrality in place of NATO membership, positions that struck many during the Cold War as dangerous. Seven years later, the Party of Democratic Socialism (PDS), which was the successor to the discredited Communist party of East Germany (SED), entered the Bundestag where it criticized unification, called for democratic socialism, and stood by fallen East German elites. The party contained a radical-leftwing association that called itself the Communist Platform (KPF) whose leader, Sahra Wagenknecht, had notoriously defended aspects of Stalinism. ${ }^{2}$

After introducing the four parties, the article presents a framework that distinguishes between approaches that focus on the supply of challenger parties and those that address the demand for these parties. It compares how the other parties treated the newcomers and considers why they did so. This comparative perspective offers insights into the challenge posed by the AfD, how distinctive the policies toward the AfD have been, and why the established parties have dealt with the AfD as they have.

\section{Four Challenger Parties}

$A f D$

In national elections held on 24 September 2017, the AfD won 12.6 percent of the second ballot vote, enough for ninety-four seats in the Bundestag. Although two deputies promptly left the party, a third followed in late 2018, another in late 2019, and a fifth had quit by early 2020, its caucus remains the third largest in parliament. The AfD is typical of new challenger parties in that it highlights issues that the established parties have neglected, ${ }^{3}$ running on an election platform that featured anti-Islam, anti-immigration, and euroskeptical positions. The party presented itself in its program as a force for the "self-preservation" of the German ethnic nation: "We want to leave our descendants a country that is still recognizable as our Germany." It called for closing Germany's borders, limiting asylum rights, and "minus immigration."

Unlike the Socialist Reich Party (SRP), which was banned in 1952, or the National Democratic Party (NPD), the AfD is less easily categorized as rightwing extremist. Scholars and journalists typically characterize it as rightwing populist, while the party describes itself as bourgeois (bürgerlich), liberal, and conservative. A recent study makes the case that the AfD is a less extreme version of a rightwing extremist party, like the Republikaner of the late 1980s. ${ }^{6}$ Although its centrist wing has lost influence since 2013, the party contains a relatively moderate faction, the "Alternative Center;" it continues to promote traditional social conservativism and market liberalism; and has many former 
Christian Democratic Union (CDU), Free Democratic Party (FDP), and Social Democratic Party (SPD) members in its ranks. Of its ninety-four original Bundestag deputies, twenty-seven had pasts in the CDU/CSU, eleven in the FDP, and ten in the SPD. Eleven AfD deputies had been members of right-wing fringe parties. $^{7}$ To the political scientist Werner Patzelt, the AfD filled party-system space vacated by the CDU: "For example, the Union was able to bind to it many of those whom they have lost by now to the AfD-and indeed to the AfD as a party, which on all kinds of positions has exactly copied that CDU, which no longer exists as the original." ${ }^{\prime 8}$ In 2017, the AfD's Bundestag caucus housed approximately twenty politicians who in the past had articulated scandalous positions regarding immigrants, Islam, National Socialism and the Holocaustor who had ties to far-right groups, such as the identitarian movement, Pegida, or the AfD's ethnic nationalist "Wing" (Flügel), whose most prominent member was Björn Höcke, the far-right nationalist leader of the AfD's regional branch in Thuringia. ${ }^{9}$

The AfD's leadership honed an anti-immigrant, euroskeptical message in which the party, typical of rightwing populist parties, claimed to represent the common people vis-à-vis an allegedly corrupt and out-of-touch elite. To the AfD, the so-called "old parties," also scorned as "cartel parties," were part and parcel of a pervasive, left-liberal elite consensus that ran roughshod over the average German's interests and values. As a protest party, it posted to the internet photos of poorly attended Bundestag plenary sessions to highlight absenteeism. One of its Bundestag deputies tweeted a photo of a ballot, with Chancellor Angela Merkel's name on it, placed on a toilet. ${ }^{10}$ In the name of supposedly "telling it like it is," the party made use of offensive, racially charged language and imagery. Bundestag caucus co-chair Alexander Gauland insulted the African-German soccer star Jerome Boateng on Twitter, spoke at a campaign rally of the "waste disposal (Entsorgung) in Anatolia" of Aydan Özoguz, the federal government's integration commissioner, and trivialized Hitler and the Nazis as "only bird droppings in our more than 1000year successful history." ${ }^{11}$ In May 2018, caucus co-chair Alice Weidel received a rebuke from Bundestag president Wolfgang Schäuble after declaring that "Burkas, headscarf girls and state-supported (alimentierte) knife men and other good-for-nothings will not secure our prosperity, economic growth and above all the welfare state." ${ }^{\prime 2}$ In the committees, away from the public eye, some AfD deputies have shown an aptitude for parliamentary work, while others have contributed little. In the Europe Committee, the AfD has slowed down the committee's work. ${ }^{13}$

Upon joining the Bundestag, the AfD proceeded to nominate Albrecht Glaser as its candidate for the Bundestag vice-president post. He had controversially 
asserted that because Islam, when a state religion, does not allegedly protect religious freedom, then Islam should not be accorded the constitutionally protected freedom of religion (Religionsfreiheit) - a view rejected by other Bundestag parties. ${ }^{14}$ The AfD unsuccessfully put Glaser up for a vote three times. It also nominated other polarizing candidates, none of whom came from its more moderate wing, to chair Bundestag committees. Peter Boehringer, who in an e-mail had referred to the chancellor as "Merkel-whore," was proposed as the budget committee head; close to the "Wing," Stephan Brandner was put forward as chair of the legal affairs committee; Sebastian Münzenmaier, accused of taking part in an attack by far-right hooligans, was nominated to chair the tourism committee. ${ }^{15}$

Early on, the AfD stirred the pot by introducing motions that would have had the federal government reject key European Central Bank policies, return refugees to war-torn Syria, reinstate border controls while turning away those trying to enter the country improperly, and ban the burka. ${ }^{16}$ Regularly, the party found ways of incorporating its opposition to migration and refugees into discussions of other seemingly unrelated topics. ${ }^{17}$ Its provocative initiatives, as well as coarse language, heckling, and insults, contributed to a combative give-and-take among the parties in parliament. ${ }^{18}$ Its populism and discourse of victimhood left the others facing a conundrum: treat the party as a normal competitor although it often did not act as such or attack it and marginalize it at the risk of undergirding the AfD's own narrative that the party was defending itself (and the German people) against vindictive political elites. To Anna Sauerbrey, the AfD follows a three-part strategy: first, cast itself as a normal, democratic competitor; second, provoke others in the Bundestag; and, third, declare itself a victim of the establishment. ${ }^{19}$ During a March 2020 Bundestag debate on rightwing terrorism, for example, Roland Hartwig (AfD) addressed the other parties that were condemning the AfD, and in particular Höcke, for having helped foster a racist climate in which the February 2020 bloodbath in Hanau occurred: "It is so nice, isn't it, when one has a common enemy and is also in agreement on where to look: the right, namely. ${ }^{20}$

The newspaper die Süddeutsche Zeitung chronicled how the AfD changed the Bundestag during its first six months in the assembly. Its caucus frequently employed derisive laughter, done in chorus, to show contempt for the other parties. The stenographer recorded laughter by the AfD 156 times (directed at the CDU sixty-eight times), while no other caucus laughed more than sixty times. The newspaper's investigation further revealed that the AfD was much less inclined than others to applaud speakers in other caucuses, and, when it did applaud, it tended to do so as a bloc, just as it often entered the chamber as a unit. The AfD made interruptions (Zwischenrufe) second only in number 
to that of the Greens. It also used language reminiscent of the Third Reich, such as "degenerate" (entartet) or "racial" (völkisch), while challenging long accepted norms on how Germany dealt with the Nazi era. ${ }^{21}$ Another study revealed that the AfD made very frequent use of question asking (Zwischenfragen) during the first forty sessions of parliament. As part of its "opposition against everyone" strategy, the AfD posed seventy-six questions to speakers from the governing parties and forty-five questions to speakers of the other opposition parties. When speakers did not take the question, AfD deputies would often jeer. In contrast, the CDU/CSU and SPD questioned AfD speakers twenty-two times, whereas the other opposition parties only posed questions to the AfD speaker twenty-nine times, nearly half of the time coming from the Greens. ${ }^{22}$

BHE

The western occupying powers initially refused to license a refugee party given their concerns, shared by the allied-approved parties, that the expellees' terrible plight would fan the flames of political extremism and revanchism. After forming in 1950, the BHE (later renamed $\mathrm{GB} / \mathrm{BHE}$ ) was an ideologically diverse party that avoided simple classification. As an outsider, it cast itself as the champion of victimized Germans ignored by an unresponsive political establishment. Unlike the AfD, however, it strove to join governments and refrained from protest in parliament. It voiced two central expellee demands: social rights in the west (Sozialrecht im Westen) and the right to return to lost homelands in the east (Heimatrecht im Osten) that reflected a reformist domestic policy and a revisionist foreign policy that contained within it a nationalist, extremist critique of the Federal Republic. ${ }^{23}$ In demanding social rights for expellees, the BHE warned that its largely destitute base might radicalize. In early 1950, the party reportedly encouraged its supporters to heckle and disrupt a political event. ${ }^{24}$

A fierce critic of denazification policies, the BHE, which may have had the most ex-Nazi functionaries as party officials, helped overcome the postwar blockade against former Nazi office holders entering politics. ${ }^{25}$ Its first national chair, Waldemar Kraft, had been an honorary captain in the ss. Its second party leader, Theodor Oberländer, had participated in Hitler's 1923 beer hall putsch and faced accusations of having committed war crimes. Although not extremist as a whole, the BHE served as a "political home for rightwing extremists and a contact partner to rightwing extremist parties, especially after the mid-1950s." ${ }^{26}$

Like the AfD, the BHE presented itself as the champion of those ignored and neglected. In a 1952 speech, Kraft cautioned that "the representatives of 
the state today are the losers of 1933, whom we can no longer believe will master the difficult tasks that lie before us. Therefore, we are the last hope of millions." ${ }^{27}$ (Sixty-five years later, the AfD's Björn Höcke would ominously warn: "The AfD is the last evolutionary, it is the last peaceful chance for our fatherland.") ${ }^{28}$ The BHE attacked the established parties as "licensed" or "old," and cast itself as the advocate of those who had paid the heaviest price for the lost war.

\section{Greens}

Formed in 1980, the Greens initially contained a right wing, centered around Herbert Gruhl who soon left the party, a center-left, often drawn from new social movement activists, and a left wing that included ecosocialists as well as Maoists coming from far-left communist splinter groups. Because the Greens accepted this latter element, thereby running afoul of the Federal Republic's prevalent anticommunism, they faced accusations that they had been subverted by extremists. ${ }^{29}$ Among its twenty-eight-person Bundestag caucus in 1983, Gerd Bastian had been in the cSU; Stefan Schulte in the FDP; Jürgen Reents in the Communist Federation (кв) and Will Hoss had been a member of the German Communist Party. ${ }^{30}$ The party had a sizable radical wing (Fundis) that called for fundamental opposition to the political and economic status quo. It featured lawyers that had represented terrorists from the farleft Red Army Faction (RAF). In 1985, two members of the Green executive committee controversially pursued a dialogue with imprisoned RAF terrorists, which aroused concerns about the party's stance on political violence. ${ }^{31}$

In their federal election manifesto in 1983, the Greens opened with a call for dramatic change: "We have not simply reached the end of the line with our economic system, but through our entire industrial civilization we have fallen into crisis, which will prove permanent if we are not ready to change course entirely." The Greens called for a "gentle, non-violent, green republic" that did not aim its guns outward and inward; for Germany to leave NATO; and for "a government that is prepared to have the Federal Republic go it alone on behalf of peace and disarmament." ${ }^{2}$

In the mid 1980s, the Green party shared with the AfD of 2017 a penchant for populism and protest. It too had arisen in opposition to the "old parties," which it deemed unresponsive to ecologists, feminists, and pacifists. After its electoral breakthrough in 1983, Petra Kelly, a prominent Green co-founder and member of parliament, declared "now the Bundestag will be occupied in order to fix it (instandbesetzt)" and that she wanted to pass along secret information to the party base because transparency was a core principle of her party. ${ }^{33}$ In parliament, the Greens, who spurned dress conventions and, 
at times, parliamentary etiquette, stirred things up through acts of protest and with combative language. The Green party deputy Jürgen Reents derided Helmut Kohl's path to CDU party chair and Bundestag caucus leader as having been bought (freigekauft) by the Flick industrial concern. When the acting Bundestag president proceeded to throw Reents out of the session and ban him for four days, Joschka Fischer interjected angrily, which resulted in his own two-day ban. Fischer countered: "With all due respect, Mr. President, you are an asshole." "Nazis" yelled out some from the CDU/CSu benches toward the Greens, an accusation that sat badly with the newcomers. ${ }^{34}$

In the December 1990 federal election, the PDS won 2.4 percent nationally, 11.1 percent of the eastern vote and seventeen seats in parliament. As successor to the East German Communist party, the PDS mostly drew its leaders and members from the SED. The PDS's internal factions ranged from social democrats to reform socialists to a radical left wing, represented by the Communist Platform. In the 1990s, the party had ties to far-left antifascist Autonomists ("Black Bloc") who regularly clashed with German police. ${ }^{35}$ Its pragmatic first two leaders, Gregor Gysi and Lothar Bisky, were dogged by allegations that they had been secret police informants in the German Democratic Republic (GDR). In its 1993 program, the PDS struck a populist note pledging that "the PDS will actively represent the interests of the people in eastern Germany vis-àvis the destructive tendency of a colonial annexation policy." ${ }^{36}$ Like the early Greens, it too opposed German membership in NATO.

In the Bundestag, the PDS irked the mainstream parties by attacking the process of German unification, representing the interests of the GDR's fallen elite, and espousing strict pacifism. The party was not averse to displays of protest. In January 1991, Gysi spoke out against the Gulf War wearing a white arm band. Gysi and other leaders engaged in a week-long hunger strike in 1994 to oppose the taxation of PDS property. With cheeky retorts during Bundestag debates, and publicity-grabbing stunts, the PDS cultivated its image as "Gysi's colorful corps." ${ }^{37}$ It portrayed itself as an intrepid voice of the east that refused to be silenced by the western establishment.

In summary, the AfD, BHE, Greens, and PDS were ideologically diverse parties, each containing relatively moderate as well as radical elements. They attacked the established parties and engaged in protest and populism. Yet important differences existed as well. The AfD is on the far right; the BHE was on the center-right; the Greens were on the center-left; and the PDS on the far left. The AfD outraged with its anti-immigrant rhetoric, widely blamed for fueling a toxic atmosphere that emboldens rightwing terrorism, and with its 
controversial policy proposals toward refugees, Muslims, and the European Union; the Green party on the basis of its radical policy prescriptions, its counterculture style and its members with far-left backgrounds; and the PDS on its SED origins, its anticapitalism, its advocacy on behalf of former GDR elite, its qualified defense of East Germany and its links with hard left groups in society. In the Bundestag, the AfD lacked a dominant centrist leadership, while pragmatic reformers in the BHE, Greens, and PDS soon led their respective parties. Whereas the AfD became more extreme after 2013 and the BHE more nationalist after 1955, the Greens and PDS moderated their programs and eventually joined the establishment, dimming memories of when they too were depicted as a threat to liberal democracy. ${ }^{38}$

\section{Strategic Responses Toward Unwelcome Newcomers}

In determining its response toward a new challenger, an established party has several options: ignore it, exclude it, contest its program and policies, cooperate with it, or incorporate parts of its agenda. ${ }^{39}$ To Bonnie M. Meguid, it can adopt a "dismissive strategy," in which it ignores the niche party's position in order not to lend it credence in the eyes of the voters. It may alternatively pursue an "accommodative strategy," in which it assumes a similar policy stance or an "adversarial strategy" in which it opposes the policy of the niche party. ${ }^{40}$

William Downs codes responses toward contemporary pariah parties across two dimensions. ${ }^{41}$ On the one hand, an established democratic party may disengage or engage those with questionable democratic credentials. On the other hand, it may pursue either a strategy of tolerance or one of militancy, that is banning or surveilling the party or curtailing its electoral activities. By combining tolerance and disengagement, the mainstream party ignores the pariah party. The coupling of militancy and disengagement leads it to ban or isolate it. The combination of engagement and militancy results in the democratic party adjusting its own policies in the hope of coopting the pariah party's issues and attracting its supporters. Finally, by combining tolerance with engagement, it pursues some form of collaboration, whether cooperation on legislation or formal coalitions. ${ }^{42}$

Stefan Rummens and Koen Abts recommended a dual strategy by which democratic parties exert pressure on an extreme party in an effort to civilize it, while adjusting their own policies in a way that addresses the extremist party voters' concerns. ${ }^{43}$ As we shall see, the established parties have followed this general recipe toward the AfD and the Greens. 
This article distinguishes between "supply-side" policies vis-à-vis the challenger in parliament and "demand-side" ones that target its voters and members. In the Bundestag, parties may adopt supply-side tactics that fit the broader strategy of what David Art has called "containment." ${ }^{44}$ They may change formal rules or depart from established practices in an effort to limit the party's presence in parliamentary bodies; they may refuse to support any proposal that it puts forth or refuse to co-sponsor joint resolutions; they may shout down, heckle or ignore its deputies in parliament; and they may call out the party as extremist or push back against its legislative initiatives in an effort to avoid normalizing the party, its language and its positions.

In contrast, demand-side policies seek to reduce societal support for the challenger party. For instance, established parties may copy its policy positions-in other words, steal its themes (Themenklau); they may educate voters as to why its policies are misguided; or they may ignore, silence, or stigmatize its proposed policies. Mainstream parties may also seek to undermine a challenger party by poaching its members and leaders, so that it has fewer, or by demonizing its members and leaders, so that fewer want to join or lead the party.

\section{Comparative Responses in the Federal Republic}

The established parties have marginalized the AfD in the Bundestag, much like they previously did vis-à-vis the Greens and the PDS, but unlike how they treated the BHE, which was received as a normal democratic competitor. They have courted AfD voters by adjusting policy positions on refugees and the Euro, a strategy seen in the approach toward the BHE and Green voters in decades past, but less apparent vis-à-vis PDS voters.

\section{AfD: Parliamentary Exclusion and Issue Inclusion}

In 2017, the other Bundestag parties rejected the AfD as a potential coalition partner. In summer 2019, the CDU's presidium and executive committee reaffirmed a 2018 party congress resolution that categorically ruled out coalitions or similar arrangements. The party leadership assured that the CDU would use all means at its disposal to enforce the resolution. ${ }^{45}$ At this time, Christian Social Union (CSU) chair Markus Söder indicated that his party opposed any and all cooperation with the AfD, even "only chit-chat over coffee in a local assembly." ${ }^{46}$ For its part, the AfD showed scant interest in joining a government or in building bridges to its competitors. Co-chair Frauke Petry had introduced a motion at the 2017 AfD party congress that proposed a 
"realistic political path of a bourgeois people's party" that could lead to the AfD's participation in coalitions, and she contrasted this approach with the "fundamentalist-oppositional strategy," which she attributed to Alexander Gauland, seeking to exert influence through external pressure. The party congress did not back her proposal. ${ }^{47}$ By September 2017, Petry had quit the party and Gauland had replaced her as federal co-chair.

Generally, the other parties have refrained from revising Bundestag rules to keep AfD deputies out of committees, offices, or honorary positions. An exception occurred when shortly before the September 2017 national election the Bundestag mandated that the longest serving deputy, rather than, as had long been the case, the oldest member of parliament, would deliver, as Alterspräsident, the opening address. This was done in order to prevent an AfD deputy, most likely Wilhelm von Gottberg, from having the honor of commencing the new legislative session. ${ }^{48}$

The established parties have scuppered AfD candidates on occasion. Although each parliamentary caucus is entitled to a vice-president post in the Bundestag presidium, a successful candidate must receive a majority of the votes (currently 355) in a secret ballot. As of March 2020, four AfD candidates had fallen short in three rounds of voting, while a fifth had come up short in his first two attempts. This suggests that some deputies are principally opposed to any AfD candidate joining a body that represents Germany's parliamentary democracy and, as such, exercises a state-supporting (staatstragende) function.

After the 2017 federal election, the Bundestag initially rejected Roman Reusch (AfD) from the Parliamentary Oversight Board ( $\mathrm{PKG}$ ), which monitors the intelligence agencies, but then approved him later. ${ }^{49}$ Whereas a Bundestag party normally places its committee chairpersons without a vote, the AfD candidates were subject to votes. Nonetheless, its three candidates were approved, albeit with votes of "no" from the Left Party among others as well as numerous abstentions. ${ }^{50}$ In May 2018, Petr Bystron (AfD), who was under investigation from the Office of Constitutional Protection for ties to the extremist identitarian movement, failed to become the chair of the subcommittee on external cultural and education policy after receiving only one vote of support in a secret ballot. ${ }^{51}$

Since 2017, the governing parties (CDU/CSU and SPD) and the other opposition parties (FDP, Left Party and Greens) have not cooperated with the AfD on legislation. Although all the parties had approved certain procedural motions, the CDU/CSU, FDP, Left Party, and Greens have not introduced any substantive proposal with the AfD nor supported any of its proposals or legislative initiatives. Moreover, they have sought to pass legislation that did 
have or need the newcomer's support. ${ }^{52}$ The Greens did back an AfD motion in a subcommittee in February 2018, but once this vote came to light they indicated that it would not happen again. ${ }^{53}$ As ideological "border parties" within the party system, the CDU and CSU face a challenge when the AfD introduces a motion whose content resembles their own stated positions. ${ }^{54}$ For instance, when the AfD proposed legislation on dual citizenship, which largely matched the CDU/CSU's position, the Christian Democrats, who are unwilling to work with the AfD, accounted for their "no" by pointing to the nationalistic language that the AfD used to support the motion. ${ }^{55}$

In the Bundestag, the established parties, especially those on the left, called out the AfD, accused it of racism, of using Nazi-like language, of historical revisionism and of fostering a hate-laden climate that brings forth political violence. They heckled its speakers and challenged its democratic credentials. In its very first Bundestag appearance on 24 October 2017, the AfD's protests regarding the Alterspräsident rule change were met with derision: "I am about to cry;" "Sophists!" and then a reference to the AfD's familiarity with Hermann Göring's methods ${ }^{56}$ In November 2017, Christine Buchholz (die Linke) panned the AfD as "a racist, a nationalist and a militaristic party," to which Left Party deputies, many Greens and some Social Democrats clapped approval. Bundestag president Schäuble urged a more moderate tone and referred the matter to the Council of Elders (̈̈ltestenrat). Schäuble, however, did not sanction Buchholz and left open the question as to whether the AfD could be called racist. ${ }^{57}$

In February 2018, Green party deputy Cem Özedemir pulled no punches in a Bundestag speech accusing the AfD of despising "this house as much as you despise the values of the Enlightenment." He also said that the party reminded him of Nazi political agitation in the "Sportpalast." ${ }^{58}$ Bundestag deputies accused the AfD of having a racial (völkisch) ideology, using Nazi language and spreading xenophobia. In September 2018, Martin Schulz (SPD) linked the AfD to Nazi-methods and said Gauland "belongs in the dustbin of German history;" Johannes Kahrs (SPD) called the AfD deputies rightwing extremist, brushed off a question from "rightwing radicals" and said to the AfD deputies "hate makes one ugly, look at yourself in the mirror." The AfD then filed out. ${ }^{59}$ The Green party interrupted AfD speakers (Zwischenrufe) more than did any other with more than a third of its interventions directed at the party. ${ }^{60}$

The established parties have not treated the AfD as a normal democratic competitor. The FDP, for instance, unsuccessfully tried to avoid sitting next to it in the Bundestag. Whereas Bundestag vice-president Claudia Roth (Greens), herself a regular target of verbal abuse from the AfD, generally 
thanked speakers upon the conclusion of their addresses she refrained from doing so for an AfD speaker. In a debate on an AfD motion, speakers took but one of the AfD's five questions (Zwischenfragen) ${ }^{61}$ Although it is commonplace for members of one caucus to applaud those from another, the established parties hardly every clapped for an AfD speaker. ${ }^{62}$ Likewise, whereas in the Bundestag budget committee it has been the convention for members to use the informal "Du" amongst themselves, some have refused when addressing AfD deputies. ${ }^{63}$ Bundestag deputies, especially those on the left, are reluctant to greet those from the AfD whose paths they cross in parliament. ${ }^{64}$

The established Bundestag parties have cited the defense of democracy as a reason to give the AfD's deputies a cold shoulder. In an October 2017 article entitled "Against Normalization!," Buchholz explained her caucus' position: "A categorical repudiation makes it possible to effectively enlighten the public regarding the AfD's nature." ${ }^{\prime 5}$ On the center-right, the CDU/Csu Bundestag caucus refused to cooperate with the AfD because, according to former caucus chair Volker Kauder, "right-radical positions are openly represented in this party. Leading politicians and Bundestag deputies express themselves in this vein without hesitation. The party calls into question the legitimacy of the Bundestag and therefore subverts our democracy." ${ }^{\prime 66}$ In a June 2019 statement, the CDU rejected cooperation with the AfD on the grounds that it had contributed to the political climate in which a rightwing extremist murdered Walter Lübke (CDU), a local politician in Hesse. ${ }^{67}$ In early July 2019, the CDU politician Friedrich Merz indicated that he supported the AfD having a Bundestag vice-president and favored a "less agitated" orientation toward AfD members and deputies. His party colleague Ruprecht Polenz tweeted: "To exclude the racial-nationalist AfD is not 'agitated' but necessary." 68

From the vantage point of the established parties, the AfD was taking away votes, parliamentary seats and resources. For these reasons, it would probably have met a chilly reception upon entering the Bundestag, even if it had had fewer controversial members or a less radical program. The AfD inflicted more electoral pain on some than others. It likely cost the FDP its place in parliament in 2013; in 2017, its strong showing left a CDU/CSU-FDP coalition without a majority. By warning of CDU-AfD cooperation, the SPD sought to put the CDU on the defensive and called upon the CDU to distance itself from a possible route to power in the eastern Länder. The CDU said it had done so and brusquely accused its coalition partner of defamation. ${ }^{69}$

The established parties have not rewritten rules to exclude the AfD in part because it would portray itself as a victim to its many supporters (an eighth of all voters in 2017). The size of the AfD's caucus also played a role; its eightynine-plus seats in parliament and its position as the largest opposition party, 
made it difficult to shut out from committees, commissions, or privileges without abandoning the principle of proportionality or without also excluding the three smaller caucuses.

On the demand side, the AfD's opponents have adjusted their policy positions to varying degrees to reduce its electoral appeal. The CDU and CSU, which lost more than a million votes to the AfD in 2017, have at times favored taking back policy ground ceded to the AfD in the hope of recovering lost support. ${ }^{70}$ Chancellor Merkel has stood by her 2015 policies during the refugee crisis, but nonetheless, has made clear that the federal government views the influx in 2015 as exceptional. It has backed the European Union's deal with Turkey to reduce the number of asylum-seekers reaching Europe. Kauder, the former chair of the CDU/CSU Bundestag caucus, attributed AfD gains to divisions within the $\mathrm{CDU} / \mathrm{CSU}$ on the refugee issue and supported the Union's efforts to attract AfD voters by toughening its policies: "Therefore it is important that we achieved, for example, in the coalition agreement the limiting of family reunification." ${ }^{" 71}$ In summer 2018, the CSU proposed turning back migrants at the border who may not be legally entitled to apply for refugee status. Analysts traced the Csu's hard line to the upcoming regional elections in Bavaria, in which the AfD was poised for strong gains. The CSU used phrases that resembled those of the AfD, such as "asylum tourism," "Islam does not belong to Germany," and the promise of a "conservative revolution."

In the 2013 Bundestag election, the FDP had fallen just short of the 5 percent mark after many of its former voters backed the AfD. During the 2017 election campaign, the Liberals called for an eventual phasing out of the Eurozone stabilization mechanism in its election manifesto, floated the possibility of easing sanctions on Russia, and maintained that Syrian refugees would be expected to return once conditions had improved in their former country. These positions led critics to describe the FDP's campaign as "AfD light."

Except for the Greens, the other leftwing parties debated amongst themselves whether to adjust their positions toward refugees at the risk of betraying core values. The Left Party lost more than 400,000 voters to the AfD in 2017 and finished behind it in eastern Germany. ${ }^{73}$ As Left Party voters, many of them working class, turned to the AfD, former party chair Oskar Lafontaine and the then Bundestag caucus co-chair, Wagenknecht, distanced themselves from the "open borders" plank in their party's platform. By early 2019, there were indications that the three left-of-center parties had chosen to deemphasize refugee policy, a politically difficult field for the SPD and Left Party, in particular. ${ }^{74}$

In addition to coopting the challenger party's positions, established parties can attempt to reduce demand for the newcomer by contributing to its 
societal stigmatization, thereby making the party less attractive to potential members and leaders. They have called upon the Federal Office of Constitutional Protection $(\mathrm{BfV})$ to probe the AfD for antidemocratic tendencies. Such calls intensified after the racially motivated terrorist attacks in Hanau. Currently the BfV is not scrutinizing the AfD as a whole. In March 2020, however, the Wing was judged to be rightwing extremist, which allows the agency to use classical espionage methods such as secret service informers. If the AfD becomes an object of official BfV observation, then this could negatively affect federal civil servants (Beamte) in the AfD. This may have contributed to the recent decision of two former police officials (Lars Herrmann and Verena Hartmann) to leave the AfD and its Bundestag caucus. Other civil servants may be heading for the exits as well. Business owners and self-employed in the caucus have claimed, given the party's stigma, that their political engagement has cost them customers and clients. ${ }^{75}$

Established parties can also attempt to weaken a challenger party by siphoning off its members and leaders. That said, Germany's major parties have shown little inclination to accept former AfD politicians into their ranks. Of the five Bundestag deputies elected on the AfD ticket who either did not join or later left the AfD caucus because of the growing influence of the party's far right, none has been included as part of another caucus. (Likewise, among the twelve AfD politicians who chose to leave their respective AfD Landtag caucuses between 2014 and late February 2017, only one became a member of an established party's caucus (SPD). ${ }^{76}$ In terms of accepting former AfD members, the FDP declared in 2015 that they were not welcome. The CDU in Thuringia also indicated that it did not want them. In March 2019, though, Csu leader Söder called upon moderates to leave the AfD and come back. ${ }^{77}$

\section{BHE: Parliamentary Inclusion and Issue Inclusion}

In the early 1950s, both the center-right parties and the leftwing Social Democrats formed coalitions with the BHE at the regional level. Although Konrad Adenauer (CDU) did not need the BHE to remain chancellor in 1953, he did require its votes for the two-thirds majority in parliament needed to amend the constitution to conform with the General Treaty and rearmament. Moreover, by bringing the BHE into a "bourgeois bloc," he further served to isolate the SPD as the lone opposition party in the Bundestag. In return, the BHE received two cabinet seats (Oberländer became expellee affairs minister and Kraft a minister without portfolio) as well as state secretary posts and numerous lower level government offices, especially in the expellee ministry. In exchange, it accepted Adenauer's foreign policy course. ${ }^{78}$ 
With the BHE's rise, the established Bundestag parties tended to the needs of the expellees in an effort to counter the new party. As Franz Neumann notes, "the parties that were already represented in the Bundestag activated their own expellee politics. As a result, the position of expellee deputies in those parties was enhanced and expellee politicians were sought after contacts (gefragte Gesprächspartner.)" ${ }^{79}$ With input from the BHE, the governing parties passed the Equalization of Burdens Act (1952) and the Federal Expellee Law (1953), which lessened expellee hardship and advanced integration. Linus Kather, a CDU politician and expellee leader who played a key role in the Equalization of Burdens law, wrung key concessions from Adenauer who was concerned that Kather and other expellee deputies would leave the party for the BHE. ${ }^{80}$

To undercut support for the newcomer party, Chancellor Adenauer and the CDU/CSU actively courted its members, leaders, and voters. In 1955, Kraft and Oberländer, the two BHE federal ministers, broke with their party over the federal government's Saar policy, remained in the cabinet, and later joined the CDU. At this time, five additional deputies left the BHE for the CDU caucus, while two others sat with the FDP. ${ }^{81}$ The rump BHE caucus entered the opposition. In 1957, the party received under 5 percent of the national vote and left the Bundestag, never to return. Its competitors, especially the CDU/ CSU, absorbed many of its voters, members and leaders, while a minority drifted off to far-right parties.

\section{Greens: Parliamentary Exclusion and Issue Inclusion}

In the 1980s, the mainstream parties kept the Greens at arm's length, excluding and isolating the new challenger party, which had the smallest of the four Bundestag delegations. In late 1983, the governing CDU/ CSU and FDP passed the federal budget. For decades, a budget subcommittee had approved funds for the intelligence agencies. In order to keep out the Greens, who were cast as a security risk, the Bundestag approved a new parliamentary control board ( $\mathrm{PKG}$ ) that would take the place of the subcommittee. It was, however, not constituted until after the budget had already passed, thereby ensuring that the Greens had no part in the decision-making. The Greens appealed to the Federal Constitutional Court, which recognized the Greens' concern, but did not require that the budget be passed according to previous procedures. ${ }^{82}$ The Bundestag did not seat a Green in the newly constituted PKG. In early 1984, it was decided that this new body would have only five members: two from the CDU/CSU, two from the SPD, and one from the FDP. ${ }^{83}$ By limiting the board's size, they could eliminate the Greens while maintaining the principle of proportionality. Tellingly, when the Bundestag debated the board's creation, an FDP deputy 
differentiated between parties that were representing the interests of the state (staatstragend) and those that were not, with the clear implication being that the Greens belonged to the latter. ${ }^{84}$

The federal parliament opted not to award the Greens a vice-presidency post in 1983 or 1987. Only in 1994 was the rule established that each fullfledged caucus (Fraktion) would have a place in the presidium, although the candidate must be voted in. In their first Bundestag debate, the Greens complained that they were being unfairly excluded from the presidium, that they should have a basic right to be represented in all committees and boards, and that their work conditions were unsatisfactory. They encountered derisive laughter, repeated interruptions, and insults. ${ }^{85}$ By way of fierce heckling, the established parties, in particular, the Christian Democrats, conveyed their conviction that the Greens did not belong in parliament. ${ }^{86}$

Why did the established parties isolate and exclude the Greens in parliament? In the mid 1980s, the CDU/Csu Bundestag caucus portrayed them as leftwing extremist, as being like Nazis, and as enemies of constitutional democracy. ${ }^{87}$ In an analysis entitled "On Route to a Green Dictatorship," Ottfried Hennig (CDU) predicted that "a green state cannot and will not in the end be a democracy. It will be a state that starts with the 'English disease' and ends as a state of Green mullahs and ecological ayatollahs." ${ }^{88}$ Rudolf Seiters (CDU) and Wolfgang Bötsch (CSU), as parliamentary whips, released a study in 1986 purporting that leftwing Greens were using the topic of environmental protection as an excuse to achieve Germany's "subjugation to Soviet hegemony." ${ }^{89}$ In early 1987, the CDU/CSU Bundestag faction released a report claiming that elements within the Greens tolerated political violence and held sympathy for terrorism..$^{90}$ This accusation would resurface decades later as a reason to isolate the AfD.

By attacking the Greens, the CDU/CSU also put pressure on the SPD, a border party. Prior to the collapse of the SPD-FDP coalition in 1982, the CDU had shown restraint toward the Greens who were challenging the SPD-led government. After 1983, however, when the Greens became a potential coalition option for the SPD, the CDU increasingly focused on their supposed extremism and the perils of a Red-Green coalition. ${ }^{91}$ This put the national SPD on the defensive, especially once its Hesse branch joined forces with the Greens in 1985 in the first regional Red-Green government. In 1986, Geißler warned of "Red-Green chaos," described the Greens as "fascistoid," as the SPD's "political Volkssturm," and as "party chair Willy Brandt's joker up the sleeve to gain office through voter deception and trickery." ${ }^{\prime 2}$

The established parties sidelined the Green party in the hope that it was a passing phenomenon. It arose as Chancellor Helmut Schmidt and the SPD 
had tacked to the center on economic and security policy. When Helmut Kohl replaced Schmidt as chancellor, it was reasonable to expect the Social Democrats to shift leftward and reabsorb those who had gone over to the Greens. Kohl predicted the Green party caucus' demise: "I give them two years, then they will cross over one by one to the SPD." "93 On the Greens' first day in the Bundestag, Bötsch warned; "ladies and gentlemen from the Greens, the page on which you are writing history will possibly be part of a loose-leaf collection. This is what we hope anyway. With our policy we will have a hand in making it so." 94

At the time the mainstream parties were marginalizing the Green party in parliament, they were elevating environmentalism within their own platforms in an effort to undercut the challenger's electoral appeal. Following the Chernobyl nuclear disaster and in light of the Greens' ascent, the Kohl government established the Federal Environmental Ministry. Heiner Geißler, CDU general secretary, later claimed that this had ensured a center-right victory in the 1986 Lower Saxony elections. ${ }^{95}$ Since the mid 1980s, the SPD politician Lafontaine pressed his party to adjust its environmental and foreign policy positions in an effort to recover votes from the Greens.$^{96}$ In late 1989, the SPD passed a new party program that called for ecological renewal, sounding themes that the Greens had helped introduce ${ }^{97}$ As the SPD chancellor candidate, Lafontaine had intended to make this a dominant campaign topic in the upcoming federal election. Although the SPD lost in December 1990, it did take votes from the West German Greens, contributing to their failure to reach 5 percent in the west and rejoin the Bundestag.

\section{PDS: Parliamentary Exclusion and Issue Exclusion}

The PDS fought a lonely battle upon entering the Bundestag in 1990. Because it had not received 5 percent of the second ballot vote, the other parties assigned it group rather than caucus status. This status, which was shared by the eastern German Alliance '90/Greens group from 1990-1994, resulted in significantly fewer parliamentary rights and much less money. The PDS fought the decision in the Federal Constitutional Court where it met with limited success, although it did acquire the right to be included on subcommittees. The court also ruled that parliament could choose the mathematical formula to allot seats proportionally, allowing the Bundestag to reduce the PDS's presence in committees and boards by applying the d'Hondt method in place of the previously commonplace Schepers method, while upholding the proportionality principle..$^{98}$ The court in a $4: 4$ decision, however, permitted the Bundestag to suspend the principality of proportionality by excluding 
the PDS from the Common Committee (Gemeinsamer Ausschuss), which in an emergency acted in place of the parliament. ${ }^{99}$ The Bundestag also kept the PDS out of the Bundestag presidium, the PKG, the committee that names judges (Richterauswahlausschuss), the G10 commission and the conference committee between Bundestag and Bundesrat. ${ }^{100}$ Although the PDS group had five minutes of floor time per every hour of debate, the Bundestag Ältestenrat, a body in which the PDS group did not have full membership rights, limited the length of Gregor Gysi's speeches from twenty to ten minutes. ${ }^{101}$ Gysi was the party's most popular orator.

In 1994 federal election, Stefan Heym, an eighty-one-year old eastern German novelist and PDS-backed candidate won an eastern Berlin election district. As the oldest Bundestag member, he gave the opening Alterspräsident speech. ${ }^{102}$ Rather than change the rules to exclude him, as would be done twenty-three years later to hinder an AfD speaker, Chancellor Kohl and his $\mathrm{CDU} / \mathrm{CSU}$ party colleagues instead chose to stare woodenly ahead during the speech, stay seated throughout, and to refrain from any applause. Later, the federal press office did not print Heym's speech in its publication Bulletin, as was customary, with the Kohl government's spokesperson, Dieter Vogel, explaining that he saw "no reason on top of that to convey the remarks of the representative of a party that stands in diametrical opposition to our democratic views." ${ }^{103}$ The Bundestag opposition parties, as well as the governing FDP, complained about the decision not to publish. Nearly six months later, the speech finally appeared in Bulletin. ${ }^{104}$

In the 1990s, the established Bundestag parties kept their PDS contacts to a minimum, refusing to support PDs-backed legislation, even if it was uncontroversial. Rather, they would put forth their own draft and not include the PDS as a co-sponsor. ${ }^{105}$ In 1992, Dagmar Enkelmann, a PDS Bundestag deputy, bemoaned that "everything is done so that our motions do not make it through committee. We would not be able to carry the motion 'Kohl is chancellor." ${ }^{106}$ The other parties also regularly interrupted and heckled PDS speakers. In 1991, Der Spiegel wrote:

good manners are suspended whenever a deputy from the PDS comes to the podium in the Bundestag. Parliamentarians from all the other caucuses unabashedly slide their chairs across the floor, rustle their newspapers and talk loudly with one another as if there were no speech from the PDS. This is exactly the point to it all. It is to make clear to the parliamentarian outcasts from the SED successor party that their presence is not valued at all. The newcomers complain that the only ones who listen to them are the "notorious hecklers." 107 
Given its small size and political isolation, the PDS had limited influence over Bundestag scheduling, which made it easier for others to ignore it. The party complained in early 1998 that its business had ended the day on fortysix of fifty Bundestag sessions. Television coverage had wrapped up and most had gone home for the evening. ${ }^{108}$

After German unification, the established parties, led by the CDU/Csu, marginalized the PDS in parliament on account of its origins, its anticapitalist program, its far left wing and its defense of fallen GDR elites. Electoral considerations played a part as well. The CDU hoped to dissuade anticommunist western Germans from backing the SPD while making it costly for the SPD to govern with the PDS in the east. In 1994, it cautioned voters that the SPD was preparing to join forces with the PDS. On its posters, it warned: "Into the Future ... But not with red socks on." A further reason to exclude the PDS was that it was thought that the party had no political future in unified Germany. Its eastern support had declined from 16.4 percent in the March 1990 East German election to 11.1 percent in the December 1990 federal election; its membership had fallen dramatically, and its calls for socialism and its defense of the GDR were out of step with the times. Most assumed the east-west cleavage, with the passage of time, would lose salience, thereby depriving the PDS of fertile ground to operate as the "authentic" voice of the east. Unlike the much larger AfD in 2017, the PDS could be marginalized and ignored in parliament by adjusting the proportionality formula or saddling it with an unfavorable Bundestag schedule.

In terms of demand-side responses, the established parties, whose leaders, members, and voters were overwhelmingly western German, generally showed little interest in copying the PDS's positions although they did attempt to be more responsive to eastern German needs. ${ }^{109}$ The PDS portrayed its own exclusion as part and parcel of the western establishment's alleged marginalization of eastern interests, biographies and identity.

Whereas in the 1950s the mainstream parties had courted BHE leaders and members, they kept former SED members at arm's length. In January 1990, the executive committee of the East German SPD passed a resolution with restrictions on former SED members joining the party. This sent a clear signal and left many former members of the once 2.3 million-member strong party with no place to turn but the PDS if they wanted to pursue political careers in unified Germany. For its part, the CDU, as the former East German prime minister Lothar de Maiziére (CDU) acknowledged, was tougher toward former SED members than it had been toward former National Socialists. ${ }^{110}$ 


\section{Conclusion}

Upon entering the Bundestag, the AfD in 2017, the BHE in 1953, the Greens in 1983 and the PDS in 1990 each presented the mainstream parties with challenges. They raised new issues that had received less attention; they attacked the so-called old parties for neglecting the interests of the people; they featured relatively moderate and more radical elements within their ranks; and they defied obvious classification as extremist. In the three most recent cases, the newcomers engaged in populism and protest to counter the policies and values of the establishment.

Although the AfD's 2017 breakthrough may mark a turning point in the German party system, its treatment in parliament has not stood out as exceptional. Instead, in its basic contours, it mirrors how the Greens and the PDS were received. All three were deemed to be unrepresentative of the interests of the state; all were ruled out as federal coalition partners; all were kept out of the Bundestag presidium; all were isolated in terms of their legislative initiatives; and all three were alternatively heckled, called out, or ignored in parliament. Those parties furthest removed ideologically from the respective newcomer, whether the leftwing parties after 2017 or the CDU/CSU in the 1980s and 1990s, confronted the upstart most vigorously. The exceptional case was in the 1950s when the established parties cooperated with the newcomer BHE from the outset.

Across the four cases, parties adjusted their policies in order to diminish the challenger's electoral appeal. After the AfD's rise, some toughened their rhetoric regarding refugees and to a lesser extent the Euro in the hope of taking the wind out of the AfD's electoral sails. This was most apparent with the CSU in 2018, but also evident with the FDP and CDU. When the BHE arose, others competed with it by empowering their own expellee politicians and through laws that benefited expellees. Following the Greens' breakthrough, the CDU/CSU, FDP and SPD developed environmental planks in their party programs and, led by the SPD, gave greater emphasis to Green party themes. In contrast, in the 1990s the established parties showed little interest in adopting PDS positions critical of unification or in meaningfully enhancing eastern German descriptive representation.

As shown in Table 1, the established parties have responded to the AfD with a combination of parliamentary exclusion and the partial inclusion of its themes. This strategy, which resembles that followed toward the Greens in the 1980s, corresponds with the recommendation of Rummens and Abts, who, as earlier discussed, advised limited repression by way of direct pressure on the extreme party in order to tame it and the crafting of policy positions 
Table 1: Supply-Side and Demand-Side Responses to New Challenger Parties

\section{Supply Side:}

Inclusion of the challenger party in parliament

\begin{tabular}{lc|c|c|}
\multicolumn{1}{c}{} & \multicolumn{1}{c}{ Less } & More \\
\cline { 3 - 3 } Demand Side: & Less & PDS & \\
\cline { 2 - 3 } $\begin{array}{l}\text { Inclusion of the } \\
\text { challenger party's } \\
\text { themes }\end{array}$ & More & Greens; AfD & BHE \\
\cline { 3 - 4 } & &
\end{tabular}

that met the concerns of the extreme party's voters. Supply-side exclusion with demand-side inclusion did not eliminate the Greens nor make them redundant, but it arguably strengthened Green reformers. It remains to be seen whether attempts to marginalize the AfD, while at the same time adjusting positions on immigration, will neutralize or tame the party. Perhaps the AfD's more moderate faction will curb the extremists' influence in an effort to head off an official observation by the Office of Constitutional Protection. So far, however, there has been little evidence of moderation as the party has moved further to the right.

Finally, a set of similar objectives shaped the established parties' responses. In the three instances of parliamentary exclusion, they cited the need to protect democracy from extremists. In each case, those parties ideologically furthest removed from the newcomer put pressure on a mainstream competitor by claiming or insinuating that it would cooperate with the outsider. For instance, the SPD has challenged the CDU/CSU to distance itself more clearly from the AfD. In the 1980s and 1990s, the CDU/CSU attacked the SPD for allegedly planning to come to power first with the Greens and then later with the PDS. In comparison, Adenauer isolated the SPD in the Bundestag by including the BHE in federal government in 1953.

The newcomer's size influenced its treatment in parliament. The small Green caucus and the small PDS group were more easily sidelined than the much larger AfD. Given its relatively large size and its provocative rhetoric, the AfD's Bundestag caucus has instead experienced repeated and aggressive "calling out" during parliamentary debates, with a "one against all; all against one" dynamic being more apparent than in the 1980s and 1990s.

In short, there is no single response toward a challenger party and, as this study has shown, a one-size-fits-all policy has not been followed nor can it be followed. Whatever the strategy, it has involved trade-offs. For instance, 
although the early embrace of the BHE and its themes reduced the party's ability to establish itself as a populist voice among expellees, it came at a cost: the increased presence of ex-Nazi functionaries in West German politics. Efforts to marginalize the Greens and the PDS may have contributed to their taming, but, as of yet, this has not moderated the AfD. The Bundestag parties are of course not the only relevant players. Prior to better Bundestag relations with the BHE, the Greens, and the PDS (and its successor the Left Party), the established parties at the regional level cracked the firewall by including each as a coalition partner. The February 2020 election of Thomas Kemmerich (FDP) as the minister-president in Thuringia, only made possible with the votes of Höcke and the AfD, at first suggested a growing reluctance among the established parties in the Länder, especially in the east where the AfD is strongest, to continue to isolate the newcomer. The national outrage that followed Kemmerich's ascent, however, resulting in his resignation, has shown that the established national parties are still strongly against any cooperation with the Alternative for Germany.

David F. Patton, who is the Joanne Toor Cummings '50 Professor of Government and International Relations at Connecticut College in New London, Connecticut, teaches classes on European politics. Patton has published books and articles on German foreign policy, political regionalism, and German party politics.

\section{Notes}

1. Fedor Ruhose, Die AfD im Deutschen Bundestag: Zum Umgang mit einem neuen politischen Akteur (Wiesbaden, 2019), esp. 17-21; Stefan Braun and Jens Schneider, "AfD im Bundestag: Attackieren! Ignorieren! Argumentieren!," Süddeutsche Zeitung, 25 April 2018; available at https://www.sueddeutsche.de/politik/afd-imbundestag-attackieren-ignorieren-argumentieren-1.3956502\#redirectedFromLa ndingpage, accessed 17 August 2018.

2. Sahra Wagenknecht, "Marxismus und Opportunismus-Kämpfe in der Sozialistischen Bewegung gestern und heute," Weissenseer Blätter, 4/1992, 12-26.

3. Airo Hino, New Challenger Parties in Western Europe: A Comparative Analysis (New York, 2012), 7-9.

4. "Programm für Deutschland. Wahlprogramm der Alternative für Deutschland für die Wahl zum Deutschen Bundestag am 24 September 2017," approved at the federal party congress, Cologne, 22-23 April 2017, 28.

5. Ibid., 29.

6. Armin Pfahl-Traughber, Die AfD und der Rechtsextremismus: Eine Analyse aus politikwissenschafticher Perspektive (Wiesbaden, 2019), 37. 
7. Peter Rütters, "Zum Sozialprofil der AfD-Abgeordneten im Bundestag: bedingt parlamentsfähig," Zeitschrift für Parlamentsfragen 50, no. 1 (2019): 70-73.

8. Werner Patzelt, "Die Union, die AfD-und meine Grundsätze," Patzelts Politik. Die Politikblog von Werner J. Patzelt, 24 June 2018, 10; available at https:// wjpatzelt.de/2018/06/24/die-union-die-afd-und-meine-grundsaetze/, accessed 20 July 2019.

9. "Das sind die Radikalen in der AfD-Fraktion," Tagesspiegel, 25 September 2017; available at https://www.tagesspiegel.de/politik/neue-abgeordnete-das-sind-dieradikalen-in-der-afd-fraktion/20361302.html, accessed 16 September 2018. For an overview of rightwing extremism in the AfD, see Thomas Klikauer and Kathleen Webb Tunney, "Germany's Secret Service Investigates the Alternative for Germany," German Politics and Society 37, no. 2 (2019), 76-97.

10. "SPD-Fraktion plant Schichtdienst im Bundestag, Tagesspiegel, 7 July 2018; available at https://www.tagesspiegel.de/politik/wegen-der-afd-spd-fraktion-plantschichtdienst-im-bundestag/22778358.html, accessed 25 July 2019; Severin Weiland, "Klo-Tweet eines AfD-Abgeordneten sorgt für Empörung," Der Spiegel, 22 March 2018; available at https://www.spiegel.de/politik/deutschland/ afd-tweet-von-stephan-brandner-zu-angela-merkel-sorgt-fuer-empoerung-a -1199359.html, accessed 31 July 2019.

11. Maria Fiedler, "Alexander Gauland und der 'Vogelschiss," Tagesspiegel, 2 June 2018; available at https://www.tagesspiegel.de/politik/afd-chef-zum-nationalsozialismus-alexander-gauland-und-der-vogelschiss/22636614.html, accessed 16 September 2018.

12. Verhandlungen des Deutschen Bundestages, $19^{\text {th }}$ Electoral Period, $32^{\text {nd }}$ Session, 16 May 2018, 2972-2973.

13. Benjamin Dierks, "Die AfD im Ausschuss-Alltag," Dlf-Magazin, June 21, 2018; available at https://www.deutschlandfunk.de/bundestag-die-afd-im-ausschussalltag.862.de.html?dram:article_id=420976, accessed 4 August 2019; Eckart Lohse and Markus Wehner, "Auf der Suche nach dem Zaubertrank," Frankfurter Allgemeine Zeitung, 5 June 2018; available at http://www.faz.net/aktuell/politik/ inland/die-union-sucht-eine-strategie-im-umgang-mit-der-afd-15622669.html, accessed 15 September 2018.

14. Ludwig Greven, “Albrecht Glaser: Der geplante Eklat,” Die Zeit, 24 October 2017; available at https://www.zeit.de/politik/deutschland/2017-10/albrecht-glaser-afdbundestag-vizepraesident, accessed 22 July 2019.

15. "Germany's AfD draws backlash for Bundestag committee chair nominees," Deutsche Welle, 24 January 2018; available at https://www.dw.com/en/germanys -afd-draws-backlash-for-bundestag-committee-chair-nominees/a-42296682, accessed 15 August 2018; "AfD-Politiker gerät wegen E-Mail in Erklärungsnot," Die Welt, 2 October 2018; available at https://www.welt.de/politik/deutschland/ article173414018/Merkel-Beschimpfung-AfD-Politiker-Peter-Boehringer-geraetin-Erklaerungsnot.html, accessed 31 January 2020.

16. Alternative für Deutschland, Fraktion im Deutschen Bundestag, "Anträge der AfD-Fraktion;" available at https://www.afdbundestag.de/antraege/, accessed 17 August 2018.

17. Katharina Brunner, Sabrina Ebitsch, Sebastian Gierke, and Martina Schories, "Das gespaltene Parlament," Süddeutsche Zeitung (April 2018); available at https://projekte.sueddeutsche.de/artikel/politik/die-afd-im-bundestag-e362724/, accessed 5 September 2018. 
18. See Eckart Lohse and Markus Wehner, "Mit Verlaub, Herr Präsident," Frankfurter Allgemeine Zeitung, 3 March 2018; available at http://www.faz.net/ aktuell/politik/inland/afd-und-die-gruenen-sorgen-im-bundestag-fuer-raueredebatten-15475773.html, accessed 17 August 2018.

19. Anna Sauerbrey, "So You've Got Populists in Your Parliament. What Next?," New York Times, 14 March 2018; available at https://www.nytimes.com/2018/03/14/ opinion/populist-germany-afd-europe.html, accessed 23 July 2019; See also Lars Rensmann, "Radical Right-Wing Populists in Parliament: Examining the Alternative for Germany in European Context," German Politics and Society 36, no. 3 (2018): 41-73, esp. 57-62.

20. Verhandlungenen des Deutschen Bundestages, $19^{\text {th }}$ electoral period, $149^{\text {th }}$ session, March 5, 2020, 18552.

21. Brunner, et al. (see note 17); See also Victor Klemperer, The Language of the Third Reich, English Language Translation (London, 2001).

22. "Wir werden sie stellen," Einfacher Dienst, 10 July 2018; available at https://einfacherdienst.de/wir-werden-sie-stellen, accessed 7 September 2018.

23. Richard Stöss, "Der Gesamtdeutscher Block/BHE" in Parteien-Handbuch: Die Parteien der Bundesrepublik 1945-1980, vol. 2, ed. Richard Stöss (Opladen, 1986), 1429-1430.

24. Michael L. Hughes, Shouldering the Burdens of Defeat: West Germany and the Reconstruction of Social Justice (Chapel Hill, 1999), 136.

25. Stöss, (see note 23), 1441; See also Franz Neumann, Der Block der Heimatvetriebenen und Entrechteten 1950-1960 (Meisenheim am Glein, 1968), 325-334.

26. Stöss (see note 23), 1440.

27. Neumann (see note 25), 23.

28. "Höcke-Rede im Wortlaut," Tagesspiegel, 19 January 2017; available at http:// www.tagesspiegel.de/politik/hoecke-rede-im-wortlaut-gemuetszustand-einestotal-besiegten-volkes/19273518-all.html, accessed 16 September 2018.

29. Helmut Fogt, "The Greens and the New Left: Influences of Left-Extremism on Green Party Organisation and Policies" in The Greens in West Germany: Opposition and Policy Making, ed. Eva Kolinsky (Oxford, 1989), 89-121; Gayil Talshir, The Political Ideology of Green Parties: From the Politics of Nature to Redefining the Nature of Politics (Houndsmill, 2002), 57-58.

30. "Grüne: Muntere Zeiten,” Der Spiegel, 11/83, 14 March 1983.

31. "Mut und Leichtsinn," Der Spiegel, 12/85, 3 March 1985, 33-34.

32. The Greens, "Diesmal die Grünen-Warum?: Ein Aufruf zur Bundestagswahl 1983," (Bonn 1983), 3-6, esp. 3, 5, 6.

33. "Grüne: Muntere Zeiten," (see note 30), 29, 32.

34. "Wenn das alles rauskommt ...," Der Spiegel, 43/1984, 22 October 1984, 73; Christoph Weckenbrock, Schwarz-Grün für Deutschland?: wie aus politischen Erzfeinden Bündnispartner wurden (Bielefeld, 2017), 83.

35. Patrick Moreau, Die PDS: Profil einer antidemokratischen Partei (Munich, 1998), 233-236.

36. Programm der Partei des Demokratischen Sozialismus, section five, 1993.

37. David F. Patton, Out of the East: From PDS to Left Party in Unified Germany (Albany, 2011), 65, 85-87.

38. David F. Patton, “The Alternative for Germany's radicalization in historicalcomparative perspective," Journal of Contemporary Central and Eastern Europe 25, no. 2 (2017): 163-180. 
39. Oskar Niedermayer, "Die AfD in den Parlamenten der Länder, des Bundes und der Eu. Bipolarität im Selbstverständnis und im Verhalten," Zeitschrift für Parlamentsfragen 49, no. 4 (2018), 905.

40. Bonnie M. Meguid, Party Competition between Unequals: Strategies and Electoral Fortunes in Europe" (Cambridge, 2008), 27-30.

41. William M. Downs, Political Extremism in Democracies: Combating Intolerance (New York, 2012), 29-32.

42. Ibid., 30-52.

43. Stefan Rummens and Koen Abts, "Defending Democracy: The Concentric Containment of Political Extremism," Political Studies 58, no. 4 (2010): 649-665, esp. 655-658.

44. David Art, "The AfD and the End of Containment in Germany," German Politics and Society 36, no. 2 (2018): 76-86, esp. 77-79.

45. "Entschließung des Präsidiums und des Bundesvorstands der CDU Deutschland zum Tod von Walter Lübke," Berlin, 24 June 2019; available at https://www.cdu. de/system/tdf/media/dokumente/2019_06_24_praesidium_buvo_walter_luebcke.pdf?file=1\&type=field_collection_item\&id=19169, accessed 15 July 2019.

46. "Auch Söder schliesst Zusammenarbeit mit der AfD aus," Spiegel, 24 June 2019, available at https://www.spiegel.de/politik/deutschland/markus-soeder-schliesst -zusammenarbeit-mit-afd-aus-a-1274098.html, accessed 15 July 2019.

47. Alternative für Deutschland, "Antragsnummer: TO4. Dr. Frauke Petry-Sachantrag zur strategischen Ausrichtung der AfD," Vorläufiges Antragsbuch zum Bundesparteitag in Köln 22. und 23. April 2017. Alternative für Deutschland (2017); available at https://www.afd.de/wp-content/uploads/sites/111/2017/04/Antragbuch-BPTApril-2017-1.pdf, accessed 27 June 2017.

48. "Eröffnung des Bundestags: AfD wehrt sich gegen Lammerts Alterspräsidentenkniff," Die Welt, 24 March 2017; available at https://www.welt.de/politik/ deutschland/article163124560/AfD-wehrt-sich-gegen-Lammerts-Alterspraesidenten-Kniff.html, accessed 31 August 2018.

49. "Geheimdienst Kontrollgremium: AfD-Politiker Reusch nun doch gewählt," February 1, 2018, available at https://www.tagesschau.de/inland/afd-reuschgeheimdienstkontrolle-101.html, accessed 31 August 2018.

50. "AfD-Abgeordnete leiten drei Ausschüsse," Bayerische Staatszeitung, 31 January 2018; available at https://www.bayerische-staatszeitung.de/staatszeitung/politik/ detailansicht-politik/artikel/afd-abgeordnete-leiten-drei-bundestagsausschuesse. html\#topPosition, accessed 21 February 2020.

51. Severin Weiland, "AfD-Politiker Bystron fällt durch,” Der Spiegel, 17 May 2018; available at http://www.spiegel.de/politik/deutschland/bundestag-afd-politikerpetr-bystron-faellt-bei-wahl-zum-kulturausschuss-durch-a-1208271.html, accessed 15 September 2018.

52. See "Parlamentsdokumentation: Statistik der Parlamentarischen Initiativen-19. Wahlperiode," Stand der Datenbank: 20:06.2019, Deutscher Bundestag; available at https://www.bundestag.de/resource/blob/533190/fda8f1cafbb6260f61e0569 d91765f3c/initiativen_wp19-data.pdf, accessed 1 August 2019. Data on bipartisan proposals provided by Dr. Michael F. Feldkamp, Redaktion Datenhandbuch, Bundestagsverwaltung, Deutscher Bundestag, 6 August 2019. "SPD und Linke zum Umgang mit der AfD," tageszeitung, 15 December 2017; available at https://taz.de/SPD-und-Linke-zum-Umgang-mit-der-AfD/!5467875/, accessed 4 August 2019. 
53. "Grüne stimmten mit der AfD: Jetzt erklären sie sich,” HuffPost, 1 June 2018; available at https://www.huffingtonpost.de/entry/gruene-afd-bundestag_de_5b0f 9068e4b0870ebd082971, accessed 14 September 2018.

54. Maria Fiedler, "Wie die AfD die anderen Parteien vorführen will," Tagesspiegel, 28 January 2018; available at https://www.tagesspiegel.de/politik/rechtspopulisten-im-bundestag-wie-die-afd-die-anderen-parteien-vorfuehren-will/20899886. html, accessed 21 July 2019.

55. Marcel Leubecher, "Schwieriger Spagat der Union beim AfD-Antrag zum Doppelpass," Die Welt, 2 February 2018; available at https://www.welt.de/politik/ deutschland/article173150877/Rueckkehr-zur-Optionspflicht-Schwieriger-Spagat -der-Union-beim-AfD-Antrag-zum-Doppelpass.html, accessed 21 July 2019.

56 . Verhandlungenen des Deutschen Bundestages, $19^{\text {th }}$ electoral period, $1^{\text {st }}$ session, October 24, 2017.

57. Matthias Meisner, "Im Streit mit der AfD mahnt Schäuble zur Zurückhaltung," Tagesspiegel, 14 December 2017; available at https://www.tagesspiegel.de/politik/ bundestag-im-streit-mit-der-afd-mahnt-schaeuble-zur-zurueckhaltung/20711356. html, accessed on 10 September 2017.

58. See a copy of the speech in "Cem Özdemir compares Germany's far-right AfD party to the Nazis in hard-hitting speech," European Greens; available at https:// europeangreens.eu/news/cem-özdemir-compares-germanys-far-right-afd-partynazis-hard-hitting-speech, accessed 10 September 2018.

59. "Schulz wünscht Gauland 'auf den Misthaufen in der deutschen Geschichte," Tagesspiegel, 12 September 2018; available at https://www.tagesspiegel.de/politik/ex-spd-chef-attackiert-afd-vorsitzenden-schulz-wuenscht-gauland-auf-denmisthaufen-in-der-deutschen-geschichte/23057642.html, accessed 5 August 2019.

60. Brunner et al. (see note 17).

61. Daniel Pokraka, "Wie die AfD die Debattenkultur im Bundestag verändert," Bayerischer Rundfunk, 2 February 2018; available at https://www.br.de/ nachrichten/deutschland-welt/wie-die-afd-die-debattenkultur-im-bundestagveraendert,QiUe9tL, accessed 10 September 2018. Ann-Katrin Müller, 'Da krieg ich 'nen Vogel,' Der Spiegel, 31/2018 (July 28, 2018), 32-35.

62. Brunner, et al. (see note 17).

63. Dierks (see note 13).

64. "Grenzsicherung," Der Spiegel, 13, 23 March 2019, 52-56.

65. Christine Buchholz, "Wider die Normalisierung!," Neues Deutschland, 29 September 2017; available at https://www.neues-deutschland.de/artikel/1065328.widerdie-normalisierung.html, accessed 24 August 2018.

66. Daniela Vates and Damir Fras, "'Politik ist kein Komödienstadl," Frankfurter Rundschau, 24 February 2018; available at https://www.fr.de/politik/politik-keinkomoedienstadl-10994743.html, accessed 25 July 2019.

67. "Entschließung des Präsidiums und des Bundesvorstands der CDU Deutschland zum Tod von Walter Lübke," 24 June 2019; available at https://www.cdu.de/ system/tdf/media/dokumente/2019_06_24_praesidium_buvo_walter_luebcke.pdf?file=1\&type=field_collection_item\&id=19169, accessed 21 February 2020.

68. "Vorstoß von Merz und Kritik aus der CDU," Der Spiegel, 6 July 2019; available at https://www.spiegel.de/politik/deutschland/friedrich-merz-fordert-unaufgeregten-umgang-mit-afd-a-1276143.html, accessed 1 August 2019. 
69. “SPD fordert CDU zu Abgrenzung von AfD,” Der Spiegel, 5 October 2018; available at https://www.spiegel.de/politik/deutschland/spd-lars-klingbeil-fordert-cduzu-abgrenzung-von-afd-auf-a-1231640.html, accessed 5 August 2019. "CDU-Chefin wirft Klingbeil 'Schmutzkampagne' vor,” tagesschau.de, 24 February 2020; available at https://www.tagesschau.de/inland/kramp-karrenbauer-klingbeil-101.html, accessed 9 March 2020.

70. Adrian Arab, "Welche Parteien die meisten Stimmen an die AfD verloren," Die Welt, 24 September 2017; available at https://www.welt.de/politik/deutschland/ article168989573/Welche-Parteien-die-meisten-Stimmen-an-die-AfD-verloren. html, accessed 5 September 2018.

71. Kauder quoted in Vates and Fras (see note 66).

72. Wolfgang Michal, "AfD light: Lindners neue FDP," Blätter für deutsche und internationale Politik, August 2017; available at https://www.blaetter.de/archiv/jahrgaenge /2017/august/afd-light-lindners-neue-fdp, accessed 15 September 2018.

73. Arab (see note 70).

74. "Grüne, SPD und Linke meiden heikle Flüchtlingspolitik," Kieler Nachrichten, 22 February 2019; available at https://www.kn-online.de/Nachrichten/Politik/SPDGruene-und-Linke-meiden-heikle-Fluechtlingspolitik, accessed 21 July 2019.

75. Tilman Steffen, "Politik auf verlorenem Posten," Zeit Online, 28 January 2020; available at https://www.zeit.de/politik/deutschland/2020-01/afd-fraktion-verena -hartmann-abgeordnete-parteiaustritt, accessed 7 February 2020.

76. Wolfgang Schroeder, Bernhard Weßels, Christian Neusser, and Alexander Berzel, "WZB-Studie: Parlamentarische Praxis der AfD in deutschen Landesparlamenten," Discussion Paper, SP V 2017-102, Wissenschaftszentrum Berlin, June 2017, 27-28; available at https://bibliothek.wzb.eu/pdf/2017/v17-102.pdf, accessed 21 February 2020.

77. "FDP lehnt ehemalige AfD-Mitglier ab," Zeit Online, 15 July 2015; available at https://www.zeit.de/news/2019-03/06/soeder-ruft-gemaessigte-afd-mitgliederzum-austritt-auf-190306-99-261400, accessed 6 August 2019. Frank Schauka, "Thüringer CDU will ehemalige AfD-Mitglieder nicht in der Partei haben," Thüringer Allgemeine, 23 May 2019; available at https://www.thueringer-allgemeine.de/politik/thueringer-cdu-will-ehemalige-afd-mitglieder-nicht-in-derpartei-haben-id225456205.html, accessed 6 August 2019. "Söder ruft gemäßigte AfD-Mitglieder zum Austritt auf," Zeit Online, 6 March 2019; available at https:// www.zeit.de/news/2019-03/06/soeder-ruft-gemaessigte-afd-mitglieder-zum-austritt -auf-190306-99-261400, accessed 6 August 2019.

78. Neumann (see note 25), 106.

79. Ibid., 21-22.

80. "Lastenausgleich: Ein Denkmal gesetzt," Der Spiegel, 26/52, 25 June 1952. "Lastenausgleich: Ein gutes Herz," Der Spiegel, 21/52, 21 May 1952.

81. “вHE-Krise/Bonn: Der Zug zu den Großen,” Der Spiegel, 30/55, 10 July 1955.

82. “Grüne: Zweiter Klasse,” Der Spiegel, 18/1984, 30 April 1984, 69-72.

83. Ibid., 72.

84. Justin Collings, Democracy's Guardian: A History of the German Federal Constitutional Court, 1951-2001 (Oxford, 2015), 212.

85. Verhandlungen des Deutschen Bundestages, $10^{\text {th }}$ electoral period, $1^{\text {st }}$ session, Bonn, 29 March 1983, 4, 12, 14, 17.

86. Jürgen Leinemann, "Arbeit für die Schmuddelkinder," Der Spiegel, 50/1984, 12 December 1984, 28-29. 
87. Paul Kraatz and Tim B. Peters, "Zwischen Abgrenzung und Annäherung. Das Verhältnis der CDU zu den Grünen 1980-1990," Historisch-Politische Mitteilungen. 20/2013, 21 October 2013, 121-146, esp. 127-132; Leinemann (see note 86).

88. Kraatz and Peters (see note 87), 128.

89. Ibid., 129.

90. Weckenbrock (see note 34), 93-94.

91. Kraatz and Peters (see note 87), 127-129.

92. “Grüne-Volkssturm der SPD," 25/1986, 16 June 1986, 31-32.

93. "Grüne: muntere Zeiten" (see note 30 ).

94. Verhandlungen (see note 85), 15.

95. "Grüne-Volkssturm der SPD" (see note 92 ).

96. Weckenbrock (see note 34), 92.

97. "Grundsatzprogramm der Sozialdemokratischen Partei Deutschland," Approved by the Program Party Conference in Berlin on 20 December 1989.

98. Bundesverfassungsgericht, Beschluss des Zweiten Senats vom 17 September 1997. - 2 BvE 4/95 - Rn. (1-99); available at http://www.bverfg.de/e/ es19970917_2bve000495.html, accessed 31 August 2018; "Schwer verträglich," Der Spiegel, 30/1991 (22 July 1991), 33-34; “PDs: Mätzchen mit Methode," Der Spiegel, 7/1995 (13 February 1995), 36-37; Findbücher/02. Bestand: Die PDS im Deutschen Bundestag (1990 bis 1994), ed. Christine Gohsmann and Jochen Weichold (Berlin, 2000), xiv-xv; Patton (see note 37), 66-67.

99. Patton (see note 37), 67; "Schwer verträglich" (see note 98 ).

100. Patton (see note 37), 67; "PDs: Mätzchen mit Methode" (see note 98).

101. "PDS: Mätzchen mit Methode" (see note 98); Findbücher/02. Bestand (see note 98), xiv.

102. See Brunner Benedikt, Der Alterspräsident: ein Konstituierungsreglement und seine Alternativen (Wiesbaden, 2012), 66-88.

103. Ibid., 78.

104. Ibid., 78-79.

105. Patton (see note 37), 65.

106. Quoted in Silke Lamback, "Karriere in der falschen Partei," Berliner Zeitung, 24 November 1992.

107. "Schwer verträglich" (see note 98), 33.

108. Patton (see note 37), 67; "Schwer verträglich" (see note 98 ).

109. Patton (see note 37), 83.

110. Ibid., 37-38. 